International Journal of Advanced Biological and Biomedical Research Available online at http:www.ijabbr.com

Volume 8, Issue 4 (2020) pp. 321-338

DOI: 10.33945/SAMI/IJABBR.2020.4.1

Original Article

\title{
Survey of Plants Used in Folk Medicine in Bali, Gashaka and Sarduana Local Government Areas Taraba State Nigeria for the Treatment of Cancers
}

\author{
Cletus A. Ukwubile ${ }^{*}$, Jude A. Odugu² ${ }^{2}$, Salihu Njidda ${ }^{3}$, Blessing 0. \\ Umeokoli' ${ }^{4}$ Abdulqadir B. Bababe ${ }^{5}$, Mathias S. Bingari6, \\ Alexander E. Angyu 6 \\ ${ }^{1}$ Department of Pharmacognosy, Faculty of Pharmacy, University of Maiduguri, \\ Nigeria \\ ${ }^{2}$ Department of Medical Microbiology, Ahmadu Bello University Teaching Hospital, \\ Shika, Nigeria \\ ${ }^{3}$ Department of Pharmaceutics and Pharmaceutical Microbiology, Faculty of \\ Pharmacy, University of Maiduguri, Nigeria \\ ${ }^{4}$ Department of Pharmaceutics and Medicinal Chemistry, Faculty of Pharmaceutical \\ Sciences, Nnamdi Azikiwe University, Awka, Nigeria \\ ${ }^{5}$ Department of Pharmaceutical chemistry, Faculty of Pharmacy, University of \\ Maiduguri, Nigeria \\ ${ }^{6}$ Department of Biological Sciences, Faculty of Science, Taraba State University \\ Jalingo, Taraba State, Nigeria \\ *Corresponding Author E-mail:doccletus@yahoo.com
}

Received: 08 February 2020, Revised: 26 February 2020, Accepted: 28 March 2020

\begin{abstract}
Background: Cancer disease has been on the increase recently in both developed and developing countries of the world resulting in about 40 million deaths annually. Chemotherapeutic measures against various types of cancer yielded little or no success at all, hence, the search for potent anticancer drugs with minimal side effects on healthy body tissues or organs continuous. This present study was aimed at surveying anticancer medicinal plants used for the treatment of cancers in three major local government areas of Taraba State, Nigeria.

Methods: Ethno-medicinal survey of indigenous herbal plants used in traditional medicine in the treatment of cancers was conducted in major communities in Bali, Gashaka and Sarduana Local Government Areas Taraba State Nigeria. Traditional medicine practitioners as well native herbalists, herbal plants and product marketers were orally interviewed by structured questionnaires. One hundred and six (106) species of plants from forty-nine (49) families were surveyed and documented in this study.
\end{abstract}

Results: Out of these, $70 \%$ of the plants were neither screened for their anticancer activity nor documented in literatures while no any members of the Families Salvadoraceae, Simaroubaceae, and Elatinaceae have ever been reported for their anticancer activity. 
Members of the Family Fabaceae have the highest number of species distribution with $15 \%$, followed by Family Asteraceae with 9\% while Family Rubiaceae and Annonaceae have 6\% and 5\% distribution respectively. The leaves of the plants were the mostly used part in the treatment of cancers in all the communities, and preparation is usually by decoction. Sides effects of these plants were generally low on observation.

Conclusions: The study therefore reveals plants that are used in folkloric medicine for the treatment of cancers, thus they represent source for new anticancer drug discovery. However, the need for conservation of these plants is of utmost important because most these plants might go into extinct as a result of urbanization pressure and timber activities in most of these areas surveyed.

Key words: Ethno-medicinal survey, cancers, Bali, Gashaka, Sarduana, Traditional medicine.

\section{Introduction}

Medicinal plants have been in use since and before human civilization and continuous efforts are being made to drive many compounds with anticancer and other medicinal properties from these plants. Globally, many natural products numbering in their thousands are of plant origin while some are from microorganisms. Some plant-based drugs have been used for centuries and there is no alternative medicine for many drugs, such as heart stimulants. Since ancient times man has explored the environment for plants that could be used to cover all their basic needs such as food, shelter, fuel and health. The number of medicinal plants has been estimated to be on the order of 40,000 to 70,000 (Timothy et al., 2007), implying that almost $25 \%$ of all plant species have one or more medicinal use in some parts of the world. This heritage from our ancestors has continued to develop in Western medicine and has resulted in the derivation and production of pure active compounds which has anticancer properties such as vincristine and other alkaloids, leading to the development of novel synthetic compounds based on this knowledge (Ramawat, 2009; Bagul et al., 2006).

Moreover, the statistics on novel anticancer drugs developed in recent decades shows that medicinal plants are a major source of inspiration for anticancer drug discovery and development (Srinivasa et al., 2006), with only 30\% introduced into the market in the period 1981-2006 being pure synthetic and all others being natural products or natural product related. These statistics also show that the number of novel chemical compounds reaching the market is decreasing every year. This is simply owing to the fact that scanty data are available on ethno-medicinal survey of plants use in the treatment of cancers and other diseases from where scientists can isolate novel anticancer compounds. Ethnomedicinal survey of anticancer medicinal plants in some countries has led to the discovery of many potential drugs of natural origin in their health system.

For instance, China has greater interest in local healthcare systems which are based on medicinal herbs, and are even considered an important and cheap alternative to treatments using conventional drugs (Bagul and Rajani, 2006; WHO, 1999; Kishan and Jean-Michaels, 2008; Ashutosh, 2007; Benzie and Wachtel-Galor, 2011). Nowadays, plants are still important sources of medicines, especially in developing countries that still use plantbased TM for their healthcare. In 1985, it was estimated in the Bulletin of the World Health 
Organization (WHO) that around $80 \%$ of the world's population relied on medicinal plants as their primary healthcare source (Michael et al., 2012). Even though a more recent figure is not available, the WHO has estimated that up to $80 \%$ of the population in Africa and the majority of the populations in Asia and Latin America still use TM for their primary healthcare needs (Pathak et al., 2006). In developed countries like the USA and Britain, plant-based traditional medicines or phyto-therapeutics are often termed complementary or alternative medicine (CAM), and their use has increased steadily over the last ten years. In USA for example, the total estimated herbal sales for 2005 was $\$ 4.4$ billion, a significant increase from $\$ 2.5$ billion in 1995 (Bagul et al., 2006).

In developing country like Nigeria, the exploding population puts pressure not only on natural medicines but also on the human population itself, whose members strive to become successful and advanced in society. This trend has resulted in increased blood pressure, anxiety, obesity-associated lipid disorders, cardiovascular diseases and diabetes. Most of these diseases result in disturbed family life, including sexual behaviour (ESCOP, 1999). Despite technological advancement in use of orthodox medicines, herbal drugs still occupy a preferential place in a majority of the population in Nigeria as well as terminal patients in the Western world countries (Iwu, 1993). Herbal drugs, in addition to being cost effective and easily accessible, have been used since time immemorial without having any side effects. The multi-target effects of herbs (holistic approaches) are the fundamental basis of their utilization. Plants have formed the basis of sophisticated traditional medicine (TM) practices that have been used for thousands of years by people in China, India, and many other countries (Upton, 1999). Some of the earliest records of the usage of plants as drugs are found in the Artharvaveda, which is the basis for Ayurvedic medicine in India (dating back to $2000 \mathrm{BC}$ ), the clay tablets in Mesopotamia (1700 BC), and the Eber Papyrus in Egypt (1550 BC) (Okafor and Ham, 1999; Gbile, 1986).

In these three local government areas of Taraba State (Bali, Gashaka and Sarduana), the use of medicinal plants in disease management and treatment is second to none because of the cultural beliefs of the people. Herbal medicines are seen to be more efficacious in managing certain diseases than the conventional drugs. Many communities in these council areas numbering up to 100 result in herbal medications in treating an ailment. Cancers are one of such diseases that are believed to be treated only in traditional way (i.e. using medicinal herbs or plants). The use of medicinal plants to treat and manage cancers in the communities and towns in these local governments dated centuries back, and this has become an inherited culture in these areas. The present study was therefore, carried out to survey the plants used for the management and treatment of cancers such as ovarian, breast, colon, prostate, and cervical cancers in communities and towns found in Bali, Gashaka and Sarduana Local Government Areas Taraba State, Nigeria. 


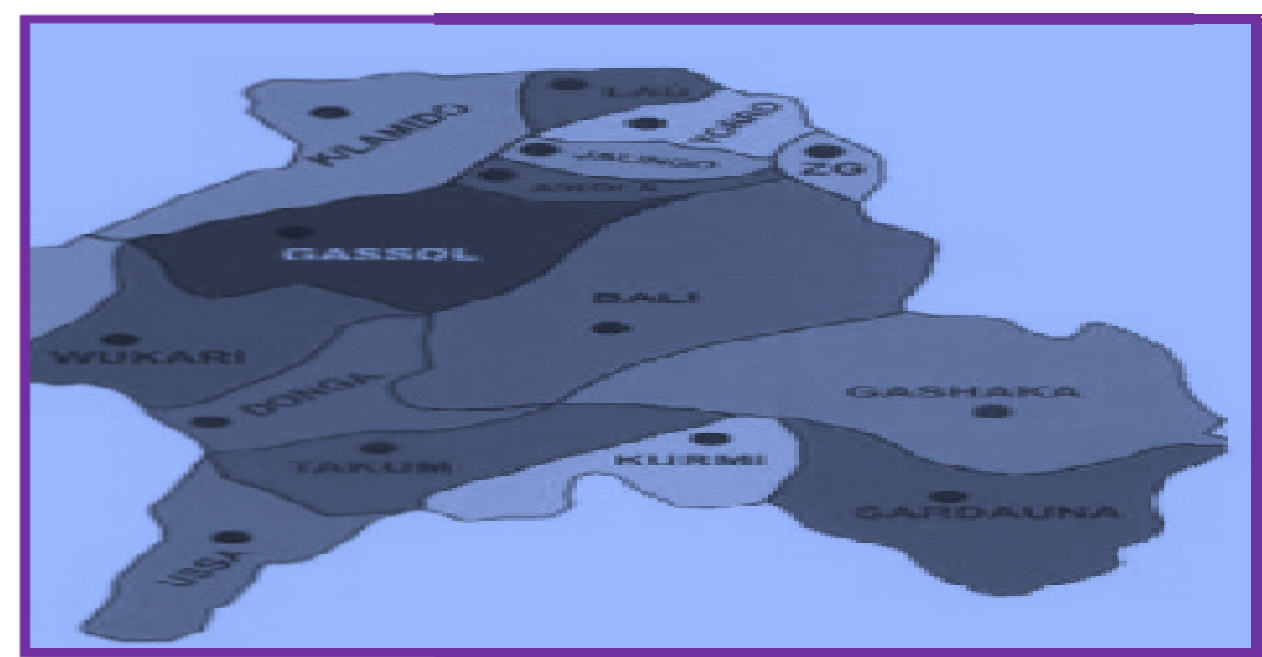

Plate 1. Map of Taraba State showing study areas

\section{Materials and methods}

\section{Study area}

Ethno-medicinal survey was carried out from February, 2017 to December, 2017 in at least 22 communities and villages in Bali and Sarduana Local Government Areas Taraba State, Nigeria. The major towns, communities and villages have a district head called Emir or Chiefs. The survey was carried out in some important communities, villages and towns with populations more than 50, 000 people. These include the following: In Bali LGA; Bali, Daniya, Jatau, Sabon Dale, Maihula, Angwar Mission, Sabon Layi, Angwar Tiv, Kwarorofa, Angwar Musa, Totondo, Garba Chede, Gazabu, Garbabi, Mayokam, Pangri, Takalafiya, Suntai, Jamtari, and Others. In Sarduana LGA; Gembu, Nguroje, Maisamari, Kankara, and others. Official languages in these areas are Hausa and Fulfulde although all tribes speak and understand Hausa language. Data were obtained through oral interviews from the herbalists, traditional medicine practitioners, traditional healers, community leaders and herb sellers with an average age of 75 years and by using phone record, and semistructured questionnaires. Attention was focused on plants used in treatment of cancers in these areas.

\section{Plants collection}

Morphological parts of the plants such as leaves, flowers, fruits, stem, roots, and stem barks of the plants were collected with the help of local plant collectors. The native of such anticancer plant was noted. The collected plants were identified and authenticated in the Department of Biological Sciences, Taraba State University Jalingo and Department of Botany, Ahmadu Bello University Zaria by plant Biologists assisted by PlantSnap App version 23 (2017). Voucher specimen numbers of these plants were deposited in the herbaria as well as plant archives of medicinal plant research laboratory Bali, Nigeria.

\section{Data collection}


Indigenous traditional medicine practitioners of the study areas were asked to answer oral questions, questionnaires as well as orally interviewed on the mode of use of these medicinal plants and parts of the plants use in order to get valid information on the ethnomedicinal use of the plants. Some of the answers were obtained through trusted interpreters who understood their languages perfectly. Herbarium press of some of the plants were made while photographic shots were used as well in some situations for easy identification. These plants were carefully recorded according to their Families in the field books used for the survey.

\section{Data analysis}

Raw data collected were expressed as mean \pm SD of original data using SPSS statistical software version 23. Data were represented in tables, bar graph and pie charts for easy interpretation.

\section{Results}

\section{Medicinal plants used to treat cancers}

From the results in Table 1 and Figure 1, members of the Family Fabaceae (Leguminosae) have the highest ethno-medicinal usage in the management and treatment of cancers out of 49 families consisting of 106 plant species. Members of the Family Asteraceae were the second largest Family surveyed in these areas. This study revealed for the first time the use of plants species from Family Fabaceae as the largest as opposed to Family Asteraceae and Annonaceae that was previously reported(Gbile, 1986). In terms of the parts of plant mostly used in cancer treatment, the leaves were most used when compared with other morphological parts.

\section{Demographic structure of surveyed areas}

In Table 2, the structured questionnaires and oral interview indicted that out of 200 total population, traditional medicine practitioners (TMP) the highest number of respondents of $27 \%$ to answers of questions on the cancers and treatment using medicinal plants while suspected cancer patients have $21 \%$ respondents. The years of experience of most traditional medicine practitioners (YTMP) were above 60 years having $12 \%$ respondents with only $2 \%$ of the respondents were below the age of 30 . The females were more than the males in terms of sex ratios.

Table 1. Medicinal plants used to manage and treat cancers in Bali, Gashaka and Sarduana Local Government Areas Taraba State Nigeria

\begin{tabular}{cccc}
\hline Botanical name & Family & Local name & Parts used \\
\hline Acanthus montanus T.And. & Acanthaceae & Agamevu(I) & Roots \\
Avicenniamarina (F)Viert & Acanthaceae & Ahon-ekan (Y) & Leaves \\
Nelsonia canescens Oerst & Acanthaceae & Manda mbaala(F) & Whole plant \\
Sansivieria liberica Ge \& Lab. & Agavaceae & Ebube-agu(I) & Stembarks \\
& & Ajakoriko (Y) & \\
& & Mooda (H) & \\
Spondias mombin Linn. & Anacardiaceae & Ichikara (I) & Stembarks \\
& & Akika(Y) &
\end{tabular}




\begin{tabular}{|c|c|c|c|}
\hline & & $\begin{array}{c}\text { Tsaada } \\
\text { lamaruudu(H) }\end{array}$ & \\
\hline & & Dukuu-hi/je (F) & \\
\hline Cussonia barteri Seem. & Araliaceae & Gwabsa(H) & Stembarks \\
\hline Annona muricata Linn. & Annonaceae & $\begin{array}{c}\text { Chowashop (I) } \\
\text { Abo (Y) }\end{array}$ & Leaves, Fruits \\
\hline Annona senegalensis Pers. & Annonaceae & $\begin{array}{c}\text { Gwanda-masari }(\mathrm{H}) \\
\text { Uburu-ocha(I) } \\
\text { Abo(Y) } \\
\text { Gwanda-daaiii }(\mathrm{H})\end{array}$ & $\begin{array}{l}\text { Leaves, Stem- } \\
\text { barks }\end{array}$ \\
\hline Cananga odorata H \&Thom. & Annonaceae & & $\begin{array}{c}\text { Leaves, } \\
\text { stembarks, roots }\end{array}$ \\
\hline Neostenanthera myristicifolia E.W & Annonaceae & Uyenghen-eze(I) & Leaves \\
\hline Landolphiadulcis (Sab.)Pichon & Apocynaceae & $\begin{array}{l}\text { Utu (I) } \\
\text { Ibo(Y) }\end{array}$ & Roots \\
\hline Voacanga africana Stapf & Apocynaceae & & Leaves \\
\hline Catharanthus roseus(L.)G.Don & Apocynaceae & Mma-agha(I) & Flowers, leaves \\
\hline Adenium obesum R.\&Sc. & Apocynaceae & Kariya(H) & $\begin{array}{l}\text { Stembarks, } \\
\text { roots }\end{array}$ \\
\hline Aloe vera (L.)Burm.F. & Asphodelaceae & Ahon-erin(Y) & Leaves \\
\hline Arnica montana Linn. & Asteraceae & & Leaves \\
\hline Crassocephalum crepidioides S.M & Asteraceae & Efo-ebolo(Y) & Whole plant \\
\hline Crassocephalum rubens S.Moore & Asteraceae & Ebire(Y) & $\begin{array}{l}\text { Roots, } \\
\text { Leaves }\end{array}$ \\
\hline Spilanthes filicaulis Jacq. & Asteraceae & $\begin{array}{c}\text { Oseana (I) } \\
\text { Awere-pepe(Y) }\end{array}$ & Whole plant \\
\hline Xanthosoma mafafa(L.)Scho & Asteraceae & Gwaazaa(H) & Rhizome \\
\hline Vernonia amygdalina Del. & Asteraceae & $\begin{array}{c}\text { Onugbo (I) } \\
\text { Ewuro(Y) } \\
\text { Shiwaakaa(H) }\end{array}$ & Leaves \\
\hline Vernoniakotschyana $\quad$ S.B.ex Wa & Asteraceae & Daumaashii(H) & Leaves \\
\hline Vernonia perrottetii $\quad$ Sc.Bi & Asteraceae & Burzuu giiwa(H) & Leaves \\
\hline Vernoniapumila Kots. & Asteraceae & Bagashi(H) & Leaves \\
\hline Crescentia cujete Linn. & Bignoniaceae & Ugbugba(I) & Fruits \\
\hline Spathodea campanulata Sem. & Bignoniaceae & $\begin{array}{c}\text { Imi-ewu (H) } \\
\text { Oruru (Y) }\end{array}$ & Leaves \\
\hline Heliotropium indicum Linn. & Boraginaceae & $\begin{array}{c}\text { Karkashin- } \\
\text { kooramaa(H) }\end{array}$ & Whole plant \\
\hline & & Agogo-igun (Y) & \\
\hline Commiphora kerstingii Engl. & Burseraceae & $\begin{array}{c}\text { Ararrabii (H) } \\
\text { Kaabi-hi/je(F) }\end{array}$ & $\begin{array}{l}\text { Stembarks, } \\
\text { Leaves }\end{array}$ \\
\hline Dialium guineense Willd. & Caesalpiniaceae & $\begin{array}{l}\text { Icheku (I) } \\
\text { Awin(Y) }\end{array}$ & Leaves \\
\hline Boscia angustifolia A.Rich & Capparaceae & $\begin{array}{l}\text { Agajin (H) } \\
\text { Anzagi (F) } \\
\text { Laoro (Y) }\end{array}$ & Leaves \\
\hline Boscia salicifolia Oliv. & Capparaceae & Zuure(H) & Leaves \\
\hline Boscia senegalensis Lam.ex.Poir. & Capparaceae & $\begin{array}{c}\text { Lilo }(\mathrm{H}) \\
\text { Gigile(F) }\end{array}$ & Leaves \\
\hline Quisqualis indica Linn. & Combretaceae & $\begin{array}{c}\text { Ata (I) } \\
\text { Oganfunfun (Y) }\end{array}$ & Leaves \\
\hline Aspilia africana D.C. Adams & Composites & $\begin{array}{l}\text { Alamejuna (I) } \\
\text { Yan-maataa (H) }\end{array}$ & Leaves, Flowers \\
\hline Ipomoea mauritiana Linn. & Convolvulaceae & $\begin{array}{c}\text { Yunyun (Y) } \\
\text { Ji-nnu (I) }\end{array}$ & Tubers \\
\hline
\end{tabular}


Citrullus vulgaris O.Ktze

Cucumis ficifolius A.Rich Cucurbita pepo Linn.

Bergia suffruticosa(D.) Fenzl. Breynia nivosa(Bull) Small Jatropha gossypiifolia Linn.

Euphorbia balsamifera Ai. Phyllanthus amarus Sch. \& Th. Phyllanthus muellerianus Exc. Indigofera astragalina (L.F) Retz Parkinsonia acukeata Linn. Parkiabiglobosa R.Br/G.Don

\section{Acacianilotica (L.)Willd}

Albiziacoriaria Welw. ex. Oliv.

Burkeaafricana Hook.

Neurotaenia mitis (A.Rich)Verd

Galega officinalis Linn.

Acaciasieberiana D.C

$$
\text { Acacia seyal Del. }
$$

Pentaclethramacrophylla Benth.

Tetrapleuratetraptera Sc.\&Th.

Vignaoleifera Linn.

Zorniaglochidiata Rc ex. DC

Psorospermumfebrifugum Spa

Harunganamadagascariensis Lam.

Vismia guineensis (L.)Choisy

Pyrenacanthastaudtii Engl. Ocimum gratissimum Linn.

Vitex simplicifolia Cham.

Hyptis spicigera Lam. Spigeliaanthelmia Linn.

\section{Cucurbitaceae \\ Cucurbitaceae \\ Cucurbitaceae}

Elatinaceae

Euphorbiaceae

Euphorbiaceae

Euphorbiaceae Euphorbiaceae

Euphorbiaceae

Fabaceae

Fabaceae

Fabaceae

Fabaceae

Fabaceae

Fabaceae

Fabaceae

Fabaceae

Fabaceae

Fabaceae

Fabaceae

Fabaceae

Fabaceae

Hypericaceae

Hypericaceae

Hypericaceae

Iccinaceae

Lamiaceae

Lamiaceae

Lamiaceae

Longaniaceae

\section{Boore(F)}

Guna (H)

Bara(Y)

Hamanya(H)

Ugbogolo (I)

Kabeewaa (H)

Kabee-re/je (F) Gboro (Y)

Baaban-giiwaa(H) Ogwueze(I)

Ake-mbogho (I)

Botuje pupa (Y)

Binidi zugu(H)

Agyaaraa(H)

Kwurukwu(I)

Nri-nwanunu(I)

Baaban-maarai(H) Jan-natu $(\mathrm{H})$ Ogiri(I),

Dorowa(H),

Naree-hi/je (F) $\operatorname{Igba}(\mathrm{Y})$

Gabaarii (H)

Gawdi (F)

Doorawamahalbi(H)

Bakin makarfo(H)

Stembarks

Leaves

Seeds

Fruits, Leaves

Leaves

Whole plant

Roots

Whole plant

Stembarks

Leaves,

Stembarks

Leaves

Leaves,

Stembarks

Stembarks,

Roots

Leaves, Roots

Whole plant

Stembarks

Farakaya $(\mathrm{H})$

Gie-daneeji(F)

Dushee $(\mathrm{H})$

Bulki(F)

Ukpaka (I)

Dawadawa(H)

Aidan (Y)

Kalangu(H)

Kara-tsiki(H)

Namijin-gadagii(H)

Cawayki(F) Ajore(Y)

Kiska wali(H)

Iru-okete( $\mathrm{Y}$ )

Daddooya (H)

Nchuanwu (I)

Efinrin(Y)

Dunyar birii $(\mathrm{H})$

Bumee-hi/je(F)

Dai fadamaa(H)

Okwu-Okpo (I)

Aparan(Y)
Stembarks

Leaves,

Stembarks

Leaves, Pods

Stembarks

Stembarks

Stembarks, Roots

Stembarks, Roots

Leaves,

Stembarks

Stembarks, Roots

Leaves

Stembarks

Whole plant

Whole plant 


\begin{tabular}{|c|c|c|c|}
\hline Lawsoniainermis Linn. & Lythraceae & Unale (I) & Roots \\
\hline Sidaacuta Burm. & Malvaceae & $\begin{array}{c}\text { Lallee }(\mathrm{H}) \\
\text { Udọ (I) } \\
\text { Esoketu (Y) }\end{array}$ & Leaves \\
\hline Pavoniahirsuta Cav. & Malvaceae & $\begin{array}{l}\text { Karkachi doki }(\mathrm{H}) \\
\text { Zmarkee }(\mathrm{H})\end{array}$ & Wholonlont \\
\hline Waltheriaindica Linn. & Malvaceae & $\begin{array}{l}\text { Nmarkee (H) } \\
\text { Nsa-eze (I) } \\
\text { Kori kodi (Y) } \\
\text { Han kufaa(H) }\end{array}$ & $\begin{array}{l}\text { Lhole plant } \\
\text { Leaves, Roots }\end{array}$ \\
\hline $\begin{array}{l}\text { Melastomastrumcapitatum Fern. } \\
\text { Azadirachtaindica A. Juss }\end{array}$ & $\begin{array}{l}\text { Melastomataceae } \\
\text { Meliaceaea }\end{array}$ & $\begin{array}{c}\text { Baikon(F) } \\
\text { Dogoyaru(I) } \\
\text { Dar bejiya(H) } \\
\text { Ganyi(F) }\end{array}$ & $\begin{array}{l}\text { Leaves } \\
\text { Stembarks }\end{array}$ \\
\hline Miliciaexcelsa (Welw.)C.C. Berg & Moraceae & $\begin{array}{l}\text { Orji (I) } \\
\text { Iroko (Y) } \\
\text { Loko(H) }\end{array}$ & Stembarks \\
\hline Myrianthusarboreus P.Beauv. & Moraceae & $\begin{array}{c}\text { Obisere (I) } \\
\text { Ewe-ade (Y) } \\
\text { Ujuju(H) }\end{array}$ & Stembarks \\
\hline Artocarpusheterophylla Lam. & Moraceae & $\begin{array}{l}\text { Ukwa-Oyibo (I) } \\
\text { Seeds }\end{array}$ & Stembarks \\
\hline Pycnanthusangolensis Warb & Myristicaceae & $\begin{array}{l}\text { Akwa-mmiri(I) } \\
\text { Akomu(Y) }\end{array}$ & \\
\hline Nymphaelotus Linn. & Nymphaeceae & $\begin{array}{c}\text { Mkpokpomere (I) } \\
\text { Ewe-Osibata (Y) } \\
\text { Badoo }(\mathrm{H}) \\
\text { Ndayri(F) }\end{array}$ & Whole plant \\
\hline Olaxsubscorpiodea Oliv. & Olacaceae & $\begin{array}{c}\text { Ifon (Y) } \\
\text { Gwaanon kurmi }(\mathrm{H})\end{array}$ & Leaves, Roots \\
\hline Baphianitida Lodd. & Papilionaceae & $\begin{array}{l}\text { Uri }(\mathrm{I}) \\
\text { Irosun }(\mathrm{Y}) \\
\text { Maiigi( } \mathrm{H})\end{array}$ & Leaves \\
\hline Talinumtriangulare Willd. & Portulacaceae & $\begin{array}{l}\text { Mgbolodi (I) } \\
\text { Gbure(Y) }\end{array}$ & Roots \\
\hline Adeniacissampeloides Harms. & Passifloraceae & $\begin{array}{c}\text { Egwusi-Ohia (I) } \\
\text { Ododo (Y) } \\
\text { Karyah(H) }\end{array}$ & Leaves \\
\hline Hilarialatifolia H.Walter & Phytolaccaceae & $\begin{array}{l}\text { Aka-ato (I) } \\
\text { Ogo(Y) }\end{array}$ & whole plant \\
\hline Digitariagayana Sta.ex.Chev. & Poaceae & Gajele(H) & Leaves \\
\hline Vossiacuspidata (Roxb.)Griff & Poaceae & $\begin{array}{c}\text { Barugu }(\mathrm{H}) \\
\text { Lingureho(F) }\end{array}$ & Leaves \\
\hline Borreriaocymoides (Burm.)D.C & Rubiaceae & Obinaze(I) & Whole plants \\
\hline Heinsiacrinita (Af)G.T & Rubiaceae & Tono poso(Y) & Stembarks \\
\hline Fadogiaagrestis Sch.ex Hierm & Rubiaceae & Bakin gagai $(\mathrm{H})$ & Whole plant \\
\hline Moreliasenegalensis A.Rich & Rubiaceae & $\begin{array}{l}\text { Tampuhi (F) } \\
\text { Akule (Y) } \\
\text { Tsintsiga(H) }\end{array}$ & Stembarks \\
\hline Morindalucida Benth. & Rubiaceae & $\begin{array}{l}\text { Njisi (I) } \\
\text { Erewo(Y) }\end{array}$ & Stembarks, Roots \\
\hline Zanthoxylumrubenscense Linn. & Rutaceae & $\begin{array}{c}\text { Akuku-nkita (I) } \\
\text { Ata (Y) } \\
\text { Fasaa kuwari(H) }\end{array}$ & $\begin{array}{l}\text { Stembarks, } \\
\text { Roots }\end{array}$ \\
\hline Salvadoriapersica Linn. & Salvadoraceae & Siwaakee-hi/je (F) & Stembarks,Leaves \\
\hline
\end{tabular}


Poulteriaalnifolia Rob.

Paulliniapinnata Linn.

Blighiasapida K.D.K

HannoaklaineanaPie. \& Engl.

Bruceaantidysenterica J.F.Mill

Nicotianarustica Linn.

SolanumnigrumLinn.

Physalisangulata Linn.

Grewiavillosa Willd.

Corchorustridens Linn.

Trema orientalis Linn.

Fleuryaaestuans (L.)Gau.

Afromomummelegueta K.Sch

Curcumadomestica Bull.Jard
Sapotaceae

Sapindaceae

Sapindaceae

Simaroubaceae

Simaroubaceae

Solanaceae

Solanaceae

Solanaceae

Tiliaceae

Tiliaceae

Ulmaceae

Urticaceae

Zingiberaceae

Zingiberaceae

Bento(H)
Baushen kurmii(H)
Ashakpa mmuo (I)
Kakasela (Y)
Yatasahiyar(H)
Okpu ulla (I)
Isin (Y)
Feso (F)
Fisaa(H)
Awuru (I)
Igigun (Y)
Kafaffi(F)

Barugu(H)

Gorongo(F)

Saada biri(H)

Dargajii(H)

Ganzema (H) Lalo(F)

Nrinwa nnunu (I) Ajenana

Agbara ubi (I)

Ofuefue(Y)

Ose-oji (I)

Atta ire (Y)

Citta $(\mathrm{H})$

Citta bodeeje(F)

Atale funfun (Y)

Gan gamau (H)
Fruits

Roots

Seeds

Stembarks

Stembarks
Roots

Roots

Leaves

Stembarks

Whole plant

Fruits

Roots

Leaves,

Stembarks

Stembarks

Seeds,Roots

Rhizome, Pod Gangamuki(F)

Note: I (Igbo), H (Hausa), Y (Yoruba), F (Fulfulde)

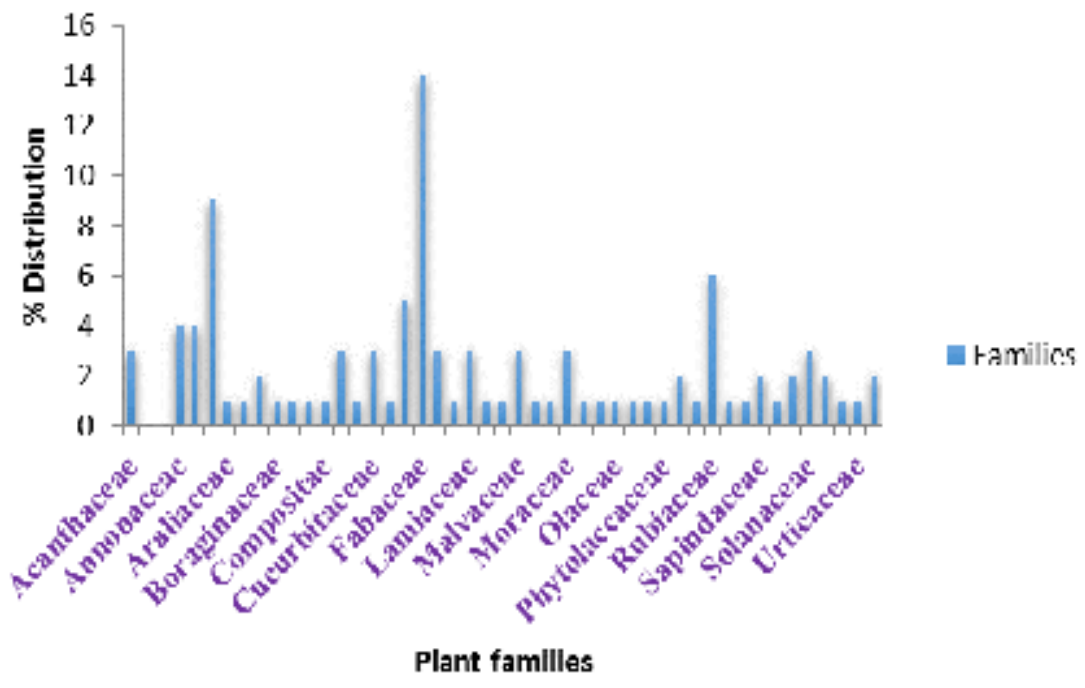

Figure1. Distribution of surveyed anticancer plants according to their families 
Table 2. Classification of the respondents on some selected parameters (N=200)

\begin{tabular}{ccc}
\hline Parameters & Index & Total respondents \\
\hline Group & TMP & $54(27 \%)$ \\
& HMS & $36(18 \%)$ \\
STMP & $<30$ & $42(21 \%)$ \\
& $30-60$ & $6(3 \%)$ \\
& $61-90$ & $25(12.5 \%)$ \\
YTMP & $>90$ & $15(7.5 \%)$ \\
& $<10$ & $8(4 \%)$ \\
& $10-30$ & $4(2 \%)$ \\
& $31-60$ & $8(4 \%)$ \\
SRES & $>60$ & $18(9 \%)$ \\
& Males & $24(12 \%)$ \\
& Females & $66(33 \%)$ \\
\hline
\end{tabular}

TMP (traditional medicine practitioners), HMS (herbal medicine sellers), SCP (suspected cancer patients), ATMP(ages of traditional medicine practitioners in years), YTMP(years of experience of traditional medicine practitioners), SRES(sexes of the respondents)

\section{Distribution of surveyed anticancer plants among various tribes}

In Figure 2, the usage of medicinal plants to treat cancers is mostly prevalent among the Fulfulde speakers which are mainly Fulani's by origin. This was followed by the Hausa speakers, while the other tribes completed the third largest usage of anticancer medicinal plants.

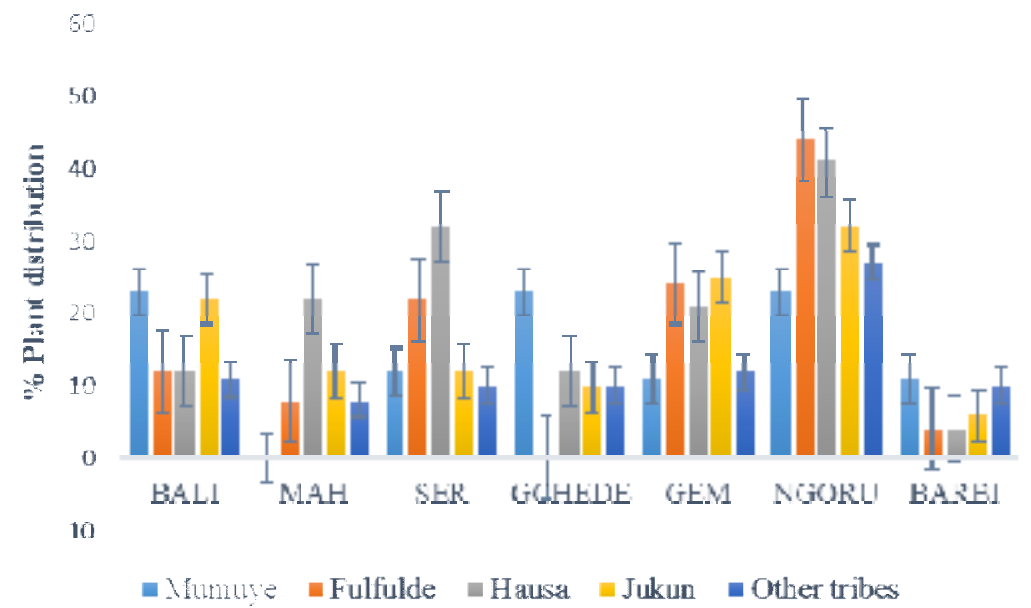

Figure 2. Plant distribution among major tribes in major study areas (\%); MAH (Maihula), SER(Serti), GCHEDE (Garba-Chede), GEM (Gembu), NGORU (Nguroje), BABI (Garbabi)

\section{Habitat distribution of surveyed anticancer plants}

The results in Figure 3 show that most of the plants used for cancer management and treatment are wild while some are cultivated and wild. Only very few are cultivated for this purpose at homes. 


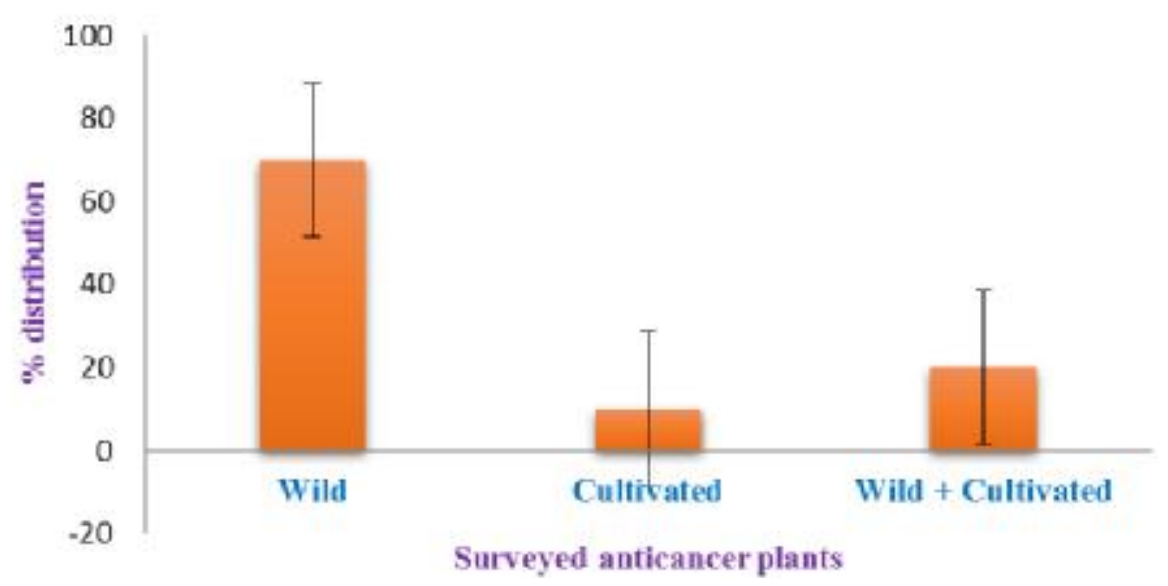

Figure 3. Habitat distribution of surveyed medicinal plants in study areas

\section{Reported anticancer activity of surveyed medicinal plants}

Also, in Figure 4, out 106 plant species surveyed in these local government areas, only $22 \%$ were reported in literatures that have cytotoxic effects on cancer cells while $78 \%$ were not reported.

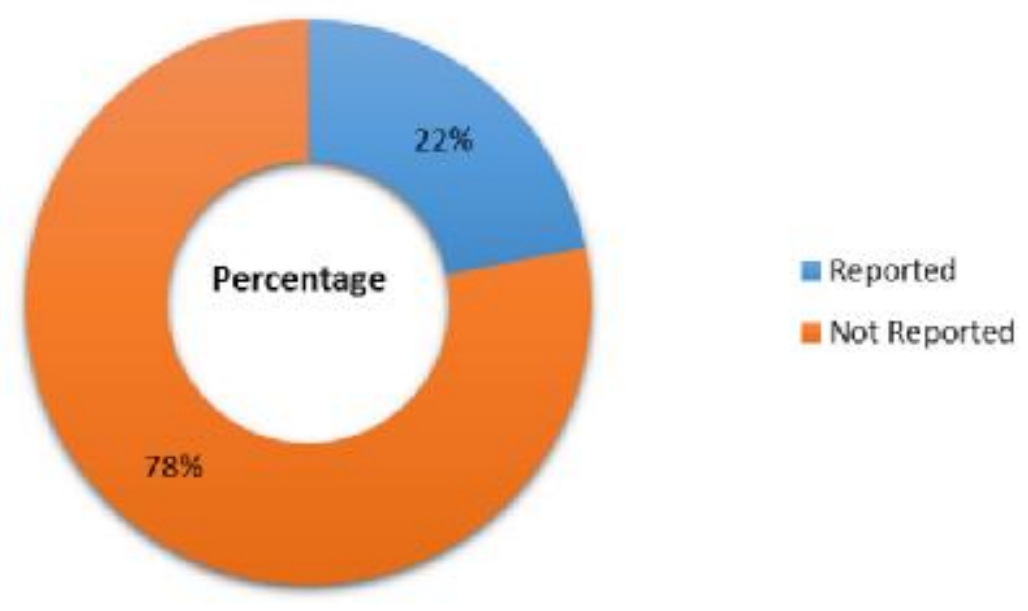

Figure 4. Anticancer status of surveyed plants in study areas

\section{Ecological characteristics of surveyed anticancer plants}

Figure 5 shows that shrubs were the most useful medicinal plants for cancer situations followed by trees and herbs. 


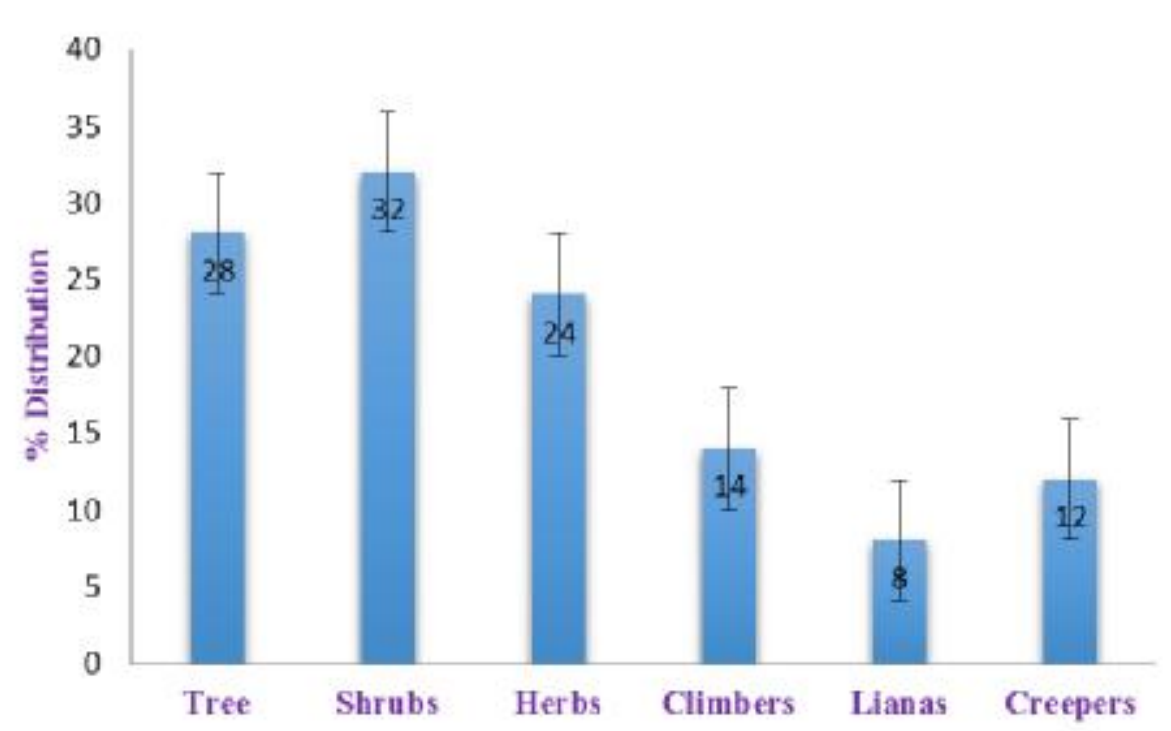

Figure 5. Nature of surveyed anticancer plants in study areas. Results are mean $\pm S E$

\section{Parts of the surveyed plants mostly used for cancer treatment}

In Figure 6 below, the plants are either used in parts or as whole plant. The leaves are the mostly used parts followed by stembarks in cancer treatment.

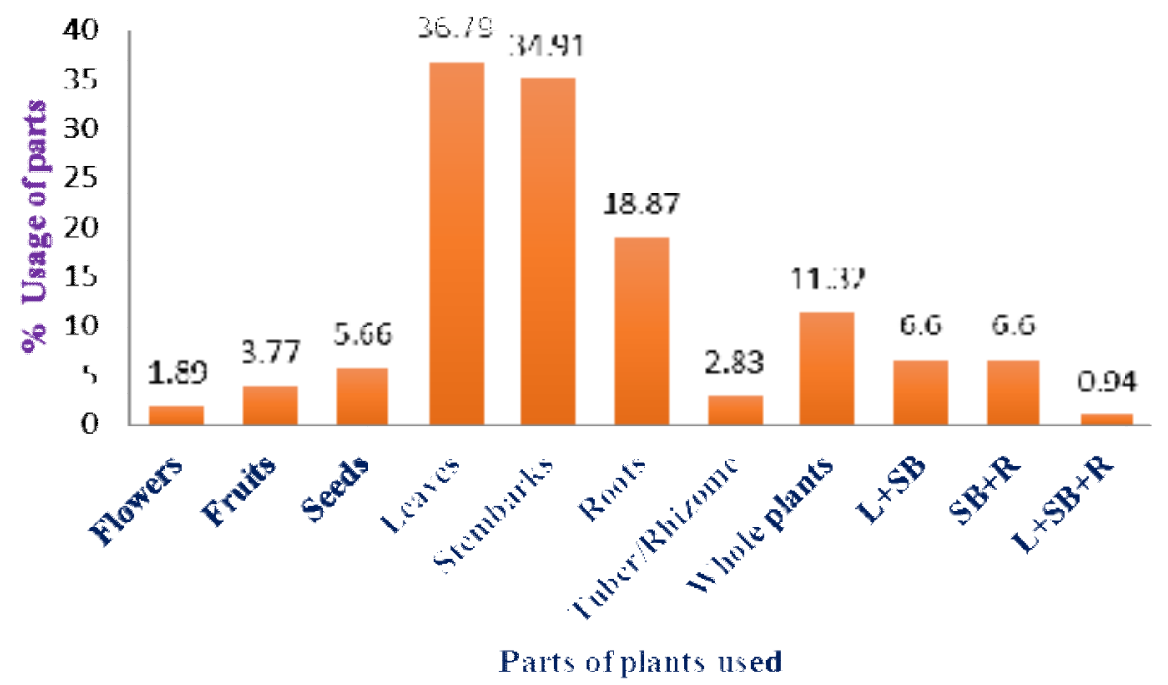

Figure 6. Percentage distribution of surveyed plants parts according to usage for cancer treatment; $\mathrm{L}+\mathrm{SB}$ (leaves plus stembarks), $\mathrm{SB}+\mathrm{R}$ (stembarks plus roots), $\mathrm{L}+\mathrm{SB}+\mathrm{R}$ (leaves plus stembarks plus roots)

\section{People's belief on the potency of surveyed anticancer plants}

In Figure 7 below, the beliefs of the peoples in the study areas on the use of medicinal plants to treat cancers is very high by $65 \%$. Only very few do not belief in the use of medicinal plants to treat cancers. 


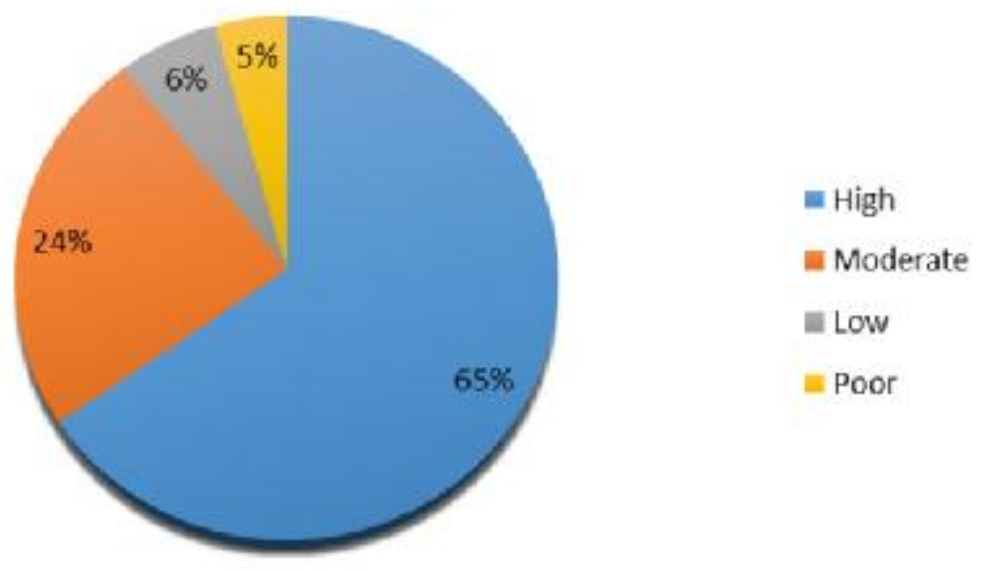

Figure 7. Beliefs of peoples of the study areas on the potency of surveyed anticancer medicinal plants on cancers

\section{Human activities threatening the conservation of surveyed anticancer plants}

In Figure 8, human activities such as farming constituted the highest threat to the conservation of these plants followed by uncontrolled timbering as well as grazing.

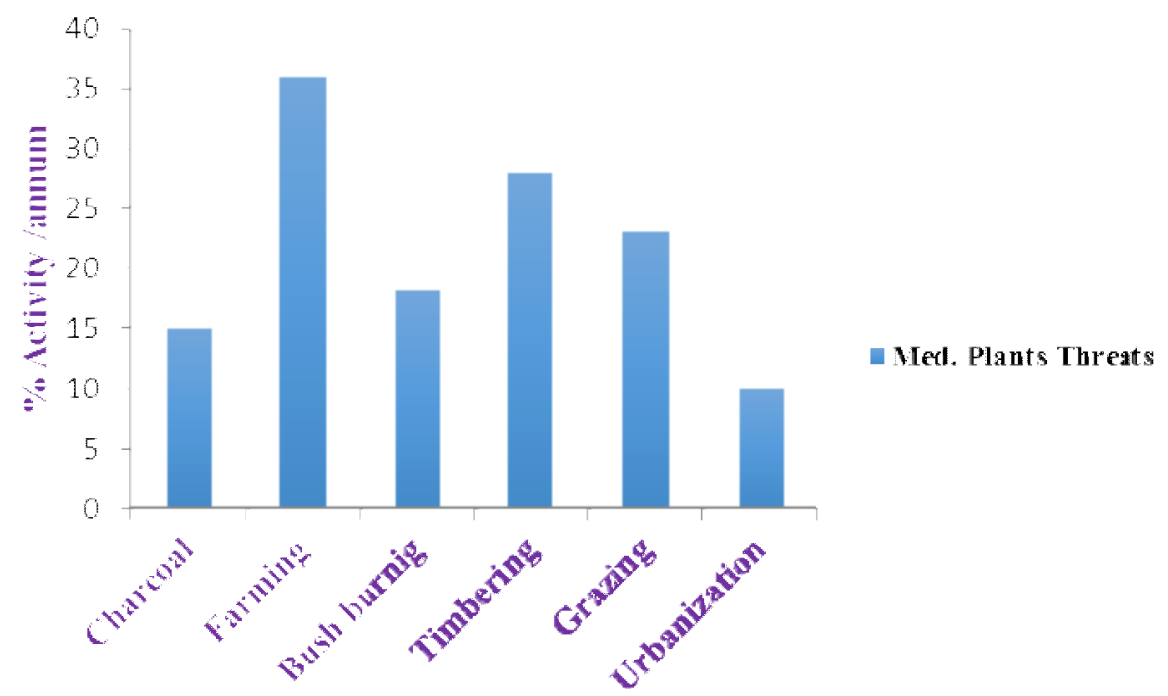

Figure 8. Human activities which constitute threat to surveyed plants in the study areas

\section{Methods used to administer preparations from surveyed anticancer plants to cancer patients}

The results in Figure 9 show that decoction of the plants parts such as leaves and stembarks is the predominant way of preparation of oral dosage of these herbal preparations with $41 \%$. It was followed by infusion preparation. 


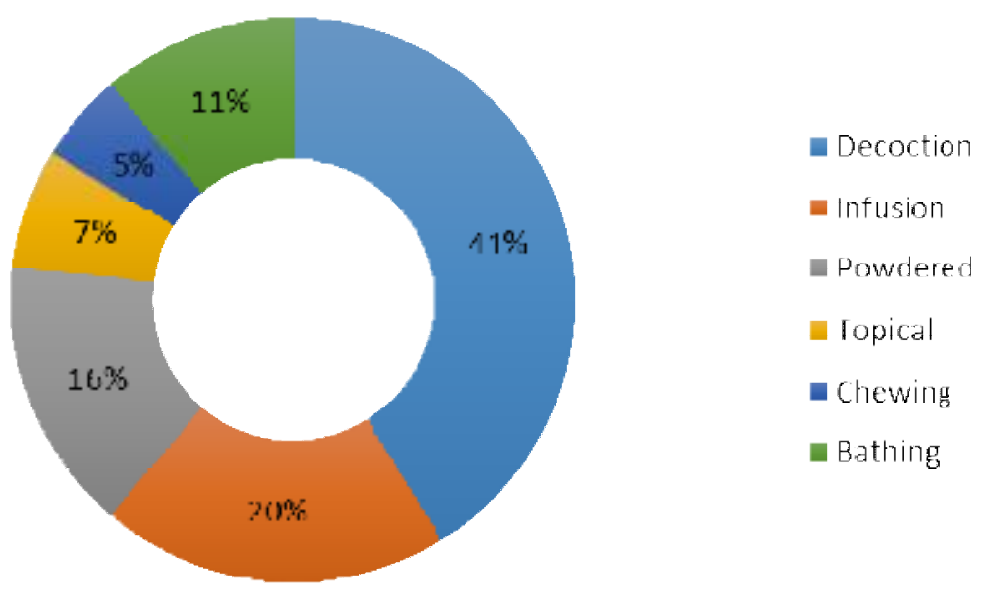

Figure 9. Methods of administering surveyed anticancer medicinal plants to patients in study areas

\section{Medicinal plants conservation in study areas}

In Figure 10 below, conservation policies aimed at preserving these surveyed anticancer plants have been good in three major towns Nguroje, Gembu and Maisamari all in Sarduana Local Government Area (L.G.A.) as well as Serti in Gashaka L.G.A. which is aimed at controlling irregular exploitation of these plants for timbers; which is a flourishing business in these study areas.

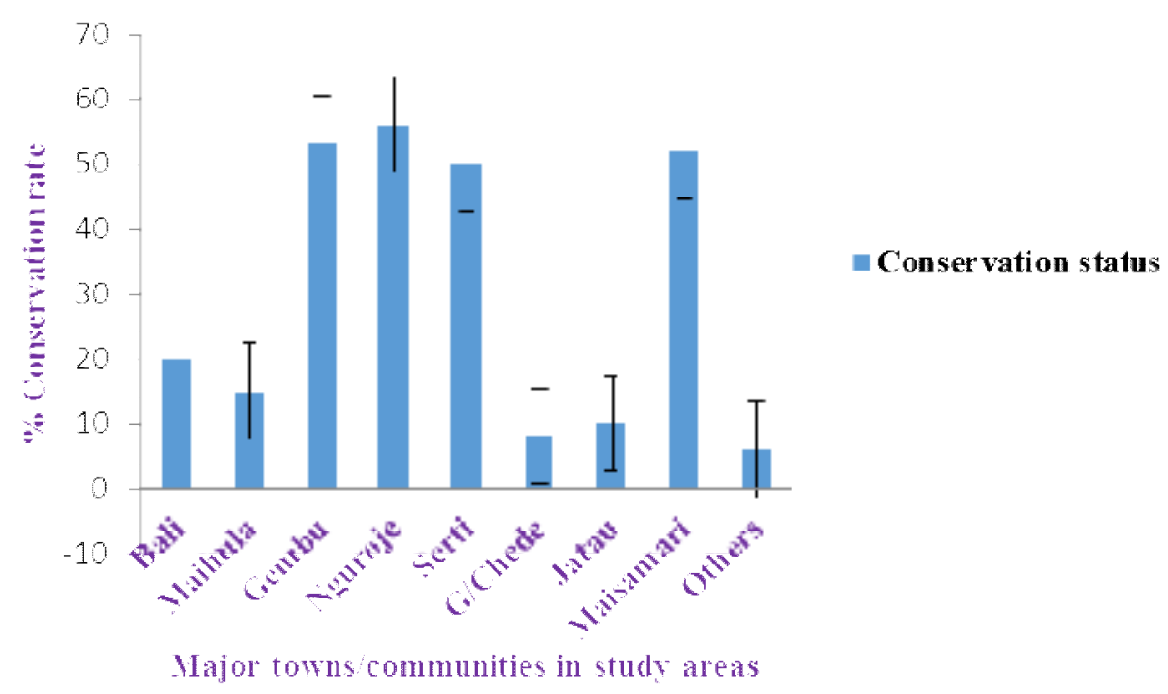

Figure 10. Conservation status of surveyed anticancer plants in major areas of study. Results are represented as mean $\pm \mathrm{SD}$ of collected data from villages in each study area

\section{Discussion}

Medicinal plants research is on greater increase nowadays because of the use of plants to manage and treat certain diseases that have defiled orthodox medicines. The side effects of 
these plants are minimum in the treatment of cancers unlike conventional anticancer drugs like doxorubicin, vincristine, cucurmin, etc. Because of the obvious advantages derived from these plants, attention is being shifted towards medicinal plants for their biologically active compounds in order to treat diseases that have resisted therapeutic measures with convectional anticancer drugs. The Hausa/Fulani traditional medicine refers to cancers as Daji or Sankarau and other associated ailments which are usually treated in the same way (Abubakar et al., 2007).

Before the evolution of orthodox medicine in Nigeria, treatment of cancers is done using these herbal plants. Nowadays, cancers are treated using conventional drugs as well as oncological radiotherapy if it is detected on time. These drugs are also cytotoxic to healthy cells or tissues in the patients resulting in more complex pathological effects due the poor selectivity of the conventional drugs (Singh and Arunachalam, 2016). In most cases, the cancers are not noticeable early enough, therefore; surgery becomes the available therapeutic measure, which is not always guaranteed.

In this study, ethno-medicinal survey of anticancer medicinal plants was carried out in towns, communities and villages in three Local Government Areas of Taraba State, Nigeria, with the aim to discovering suitable plants with biologically active compounds against cancers. From the study, 106 plant species from 49 Families were surveyed. The result showed that Family Fabaceae (Leguminosae) has the highest percentage distribution followed by Family Asteraceae in terms of usage for treatment of cancers such breast, ovarian, prostate, and cervical cancers (Table 1, Figures1 and 4). Some plants among the Family Fabaceae and Asteraceae such as Vernonia amygdalina, and Vernonia pumila have been reported to be cytotoxic against breast cancer cell line (Iwu, 1993). Anticancer activities of Annonasenegalensis, Catharanthus roseus, and Annonamuricata have well been documented, and many compounds have been derived which have potent effects on cancer cell lines. Basically, the leaf decoction; which is in moderate doses was the mostly used method of administration of these medicinal plants in these areas followed by stembarks and roots. According to the study, healing from the preparation of plant extracts was neither time nor concentration dependent but depends on the plant species and the mode of preparation. This finding was in line with the report by (Mike etal. 2010), who reported likewise, but contrary to the findings of (Sawadogo et al. 2012), who reported that the roots and stembarks followed by the seeds as the mostly used parts in disease treatment.

Most of the plants surveyed in these areas have also been reported to be used in the treatment of various diseases in different parts of Nigeria by some researchers and authors of medicinal and natural products (Ene and Atawodi, 2012; Odugbemi, 2006; Mohammed et al., 2014). The use of these medicinal plants to treat cancers in the study areas received overwhelming beliefs of $65 \%$ of the respondents (Figure 7), and this percentage consists of $27 \%$ traditional medicine practitioners (TMP) with $12 \%$ above 60 years of age (Table 2). The study further showed that the use of medicinal plants to treat cancers was prevalent among Fulfulde and Hausa tribes of these Local Government Areas (Figure 2). According to the present study, shrubs were the mostly used medicinal plants as anticancer agent followed by trees and herbs (Figure 5). Despite the success recorded in the use of medicinal plants to treat cancers in these areas, the fact that $79 \%$ of these plants were collected from the wild still poses many challenges due to high farming and timbering activities in some of the study areas (Figures 3, 8 and 10). This is not surprising at all because the attention of the government has not moved towards use of medicinal plants to treat cancers or any disease. 
Finally, the use of plants morphological parts such as the leaves, stembarks, roots, fruits, seeds, and flowers in the treatment of breast, ovarian, cervical and prostate cancers have become a norm in the study areas. This is because every medicinal plants in the surveyed areas has a local name with which it is called, and this tradition is usually passed onto younger generations for sustainability. Cancer researchers are therefore recommended to look towards the direction of authenticating the anticancer claim of these surveyed plants with a view to providing valid scientific justification, and further pave way for future study on the anticancer activities of these medicinal plants. This study was based on ethnomedicinal anticancer claims by herbal medicine practitioners in these areas. These claims have not been scientifically verified on plants that were not reported before.

\section{Conclusions}

From this study, there is no doubt that use of medicinal plants to treat cancers in the study areas has existed for decades. However, the study identifies lack of proper hygiene in the formulation of medicinal plants preparations, excessive farming and timbering activities as well as un-regulated grazing by herders as major threats to the conservation of these medicinal plants in these areas. Adequate measures of conservation of these plants is very crucial for bright future of traditional medicinal plants in the areas. This study therefore provides an insight on the anticancer plants in these parts of Nigeria for scientific research on the acclaimed use in cancer treatment for proper validation. It further revealed vital link for isolation of bioactive compounds with cytotoxic effects on cancer cells as well as for anticancer drug discovery.

\section{Significance of the statements}

The findings from this ethno-medicinal/ethno-botanical survey will be very crucial for conservation biologists and pharmacognocists in order to checkmate the activities of humans to prevent these plants from extinction. The study further revealsplants that are used for the treatment of cancers locally that have never been reported, and will help natural product researchers in developing a start-up plan towards anticancer drug discovering.

\section{Acknowledgments}

We are thankful to all the traditional medicine practitioners as well as our interpreters in Hausa, Fulfulde, Jukun, Mumuye, Yoruba and Igbo, who helped us in translating the answers of respondents that were all non-English speakers, and also for providing the correct spellings to local names of surveyed plants.

\section{References}

Abubakar, MS, Musa, AM, Ahmed, A, Hussaini, IM. (2007). The Perception and Practice of Traditional Medicine in the Treatment of Cancers and Inflammations by the Hausa and Fulani Tribes of Northern Nigeria. J. Ethnopharm., 111:625-629.

Ashutosh, K. (2007). Medicinal Chemistry. New Age Intl. Pub. New Delhi, India,pp 960. 
Bagul, MS, Pathak, SB, Ravishankara, MN, Rajani, M.(2006). Phytochemical standardization of polyherbal Unani formulation Sharbat-E-Ejaz. In: Abdin MZ, Abrol YP (Eds) Traditional Systems of Medicine. Narosa Publishing House, New Delhi, India, pp. 131.

Bagul, MS, Rajani, M. (2006). Phytochemical evaluation of Chyavanprash. In: GovilBenzie, IF, Wachtel-Galor, S. (2011). Herbal Medicine. In Herbal Medicine: Biomolecular and Clinical Aspects, 2nd ed.; CRC Press-Taylor\& Francis: Boca Raton, FL, USA, pp. 391.

Ene, AC, Atawodi, SE. (2012). Ethnomedicinal Survey of Plants Used by the Kanuris of North Eastern Nigeria. Indian J. Tradit. Knowledge, 11(4):640-645

ESCOP. (1999). European Scientific Cooperative on Phytotherapy. Monographs on Medicinal Uses of Plant Drugs, ESCOP Secretariat, UK.

Gbile, ZO. (1986). Ethnobotany, taxonomy and Conservation of medicinal plants.' In: "The state of medicinal plants research in Nigeria". Sofowora, A. (Ed.) University of Ibadan Press, Nigeria: 13-29.

Iwu, MM. (1993). Handbook of African Medicinal Plants.CRC Press Inc., Florida.

Kishan, GR, Jean-Michel, M. (Eds.) (2008). Bioactive Molecules and Medicinal Plants. Springer-Verlag Berlin Heidelberg, pp. 391.

Michael, H, Joanne, B, Gibbons, S, Elizabeth, M, Williamson, A, Kinghorn, D, Phillipson, JD. (2012). Fundamentals of Pharmacognosy and Phytotherapy 2nd Edition. Churchill Livingstone Elsevier, USA. pp. 337.

Mike, O, Soladoye, N, Amusa, A, Salmot, OR, Emmanuel, CC, Ayanbamiji, AT. (2010). Ethnobotanical Survey of Anti-Cancer Plants in Ogun State, Nigeria. Annal. Biol. Res., 1(4):261-273.

Mohammed, ZK, Daja, A, Hamza, HG, Gidado, A, Hussaini, IM. (2014). Ethnomedicinal Survey of Folkloric Plants Used in Managing Breast Cancers by the Traditional Medical Practitioners of North- East Nigeria. J. Med. Appl.Biosci., 6(1):29-43.

Odugbemi, T. (2006). Outlines and Pictures of Medicinal Plants from Nigeria. University of Lagos Press, Nigeria. URL: http//:www.medicinalplantsinnigeria.org.

Okafor, J, Ham, R. (1999). Issues in African Biodiversity, No. 3: Identification, Utilization, and Conservation of Medicinal Plants in South-eastern Nigeria.

Pathak, SB, Bagul, MS, Rajani, M. (2006). Multiple marker based Standardization of a polyherbal Unani Formulation Majoon-E-Jograj Gugal. In: Abdin MZ, Abrol YP (Eds). Traditional Systems of Medicine. Narosa Publishing House, New Delhi, India, pp. 113.

Ramawat, KG. (2009). Herbal Drugs: Ethnomedicine to Modern Medicine (Ed.). SpringerVerlag Berlin Heidelberg, pp. 414. 
Sawadogo, WR, Schumacher, M, Teiten, MH, Dicato, M, Diederich, M. (2012). Traditional West African Pharmacopeia, Plants and Derived Compounds of Cancer Therapy. Biochem. Pharmacol., 84(10):1225- 1240.

Singh, VK, Arunachalam, C. (Eds) (2016). Recent Progress in Medicinal Plants - Search for Natural Drugs, Vol. 13. Stadium, Houston, pp. 251.

Srinivasa, H, Bagul, MS, Ravishankara, MN, Rajani, M. (2006). Phytochemical standardization of Unani formulations - Sharbat-E-Nilofer and Majoon Zabeeb. In: Abdin MZ, Abrol YP (Eds) Traditional Systems of Medicine. Narosa Publishing House, New Delhi, India, pp. 139.

Timothy, ST, Kingston, RL. (2007). Herbal Products. Toxicology and Clinical Pharmacology 2nd Edition (Eds.).Humana Press, Totowa New Jersey USA, pp. 300.

Upton, R (Ed.). (1999). American Herbal Pharmacopoeia. American Herbal Pharmacopoeia, California, USA.

WHO. (1999). WHO monographs on selected medicinal plants. Vol. 1 and 2. World Health Organization, Geneva.

How to cite this article:Cletus A. Ukwubile, Jude A. Odugu, Salihu Njidda, Blessing O. Umeokoli, Abdulqadir B. Bababe, Mathias S. Bingari, Alexander E. Angyu, Survey of Plants Used in Folk Medicine in Bali, Gashaka and Sarduana Local Government Areas Taraba State Nigeria for the Treatment of Cancers. International Journal of Advanced Biological and Biomedical Research, 2020, 8(4), 321-338. Link: http://www.ijabbr.com/article 38756.html 